\title{
Polish Jurisprudence in the 2oth Century: A General Overview
}

\author{
Tomasz Bekrycht \\ Legal Theory and Legal Philosophy Department, Faculty of Law and \\ Administration, University of Lodz, Lodz, Poland \\ tomaszbekrycht@wpia.uni.lodz.pl \\ Rafat Mańko \\ Amsterdam Centre for Transformative Private Law (ACT), Faculty of Law, \\ University of Amsterdam, the Netherlands; Department of Jurisprudence, \\ Faculty of Law, Administration and Economics, University of Wrocław, \\ Poland \\ r.t.manko@uva.nl
}

\begin{abstract}
The present paper provides a general overview of the sources of inspiration and main currents in Polish jurisprudence in the $20^{\text {th }}$ century, especially in the post-War and contemporary period. The paper notes that the main sources of inspiration in the early $20^{\text {th }}$ century included Leon Petrażycki, Bronisław Wróblewski, Czesław Znamierowski and Jerzy Lande, who exerted a great influence on the first generation of Polish post-War legal theorists. The Lvov-Warsaw school of analytical philosophy also had a huge impact on Polish jurisprudence, as the school to a large extent determined the research questions posed by Polish legal theorists. Indeed, analytical legal theory can be said to have dominated Polish jurisprudence from the 1950s up to the end of the 1980s. After 1989, a broad current of new philosophical approaches to jurisprudence emerged, including legal hermeneutics and philosophies of interpretation, legal ethics, postmodern and critical legal theory, the phenomenology of law as well as an original Polish achievement - the legal theory of 'juriscentrism'.
\end{abstract}




\section{Keywords}

Jurisprudence - Poland - theories of interpretation - methodology of legal research Polish legal culture - analytical legal theory - legal hermeneutics - postmodern legal theory - juriscentrism

\section{Introduction}

In the Polish sub-division of legal disciplines belonging to the broad field of jurisprudence, there is a tradition that distinguishes between legal theory and the philosophy of law. There is an on-going academic debate about the exact criteria for differentiating between the two, and certain original proposals have been made in this regard. However, as a rule of thumb one could say that 'legal theory' is usually associated with the analytical, i.e. language-focused approach to jurisprudence (analytical jurisprudence), characterised by an 'antiphilosophical', 'scientistic' and 'apolitical' approach. ${ }^{1}$ Legal theory in this sense was undoubtedly dominant in Polish jurisprudence during the post-War period, sharing this role only with a sociology of law that was oriented towards scientism and empiricism.

In contrast, 'philosophy of law' denotes a more philosophically oriented approach to jurisprudence, where the researcher moves either 'from philosophy to law' or 'from law to philosophy,', but the role of philosophy in general reflexion on law remains crucial. Philosophy of law, in contrast to legal theory, can hardly be apolitical, as it engages with political and social theory in the consideration of legal phenomena. The philosophy of law as a discipline flourished in the inter-War period and gained momentum after 1989, a fact which is linked to the dismantling of actually existing socialism.

A third branch of jurisprudence, also well established in the Polish academic field, is the sociology of law, whose origins in Poland can be traced back to Leon Petrażycki, ${ }^{3}$ one of the founding fathers of the discipline.

The aim of the present paper is to provide a birds' eye view of Polish jurisprudence in the post-War (1945-1989) and contemporary periods (after 1989).

1 Marek Zirk-Sadowski, "Metodologie teorii prawa a problem polityczności prawoznawstwa. Aspekt behawioralny i intensjonalny" [The Methodologies of Legal Theory and the Problem of the Political Character of Legal Scholarship: Behavioral and Intensional Aspect], 110 Przegląd Prawa i Administracji (2017), 51-62.

2 Marek Zirk-Sadowski, Wprowadzenie do filozofii prawa [An Introduction to the Philosophy of Law] (LEX, Warszawa, 2011), $19 f f$.

3 Cf. Jan Woleński, "On Leon Petrażycki's contribution to theory and philosophy of law," 17 Studia Historiae Scientiarum (2018), 365-389. 
Obviously, the year of Poland's transformation from actually existing socialism to capitalism, democracy and the rule of law - which occurred in stages between 1988 and 1991 - had an immense impact upon jurisprudence, by ending the official hegemony of the Marxist-Leninist orthodoxy and opening up Polish legal theorists to currents that had already gained momentum in the West, including legal hermeneutics, legal naturalism, legal ethics, the phenomenology of law, and postmodern legal thinking. The end of actually existing socialism also meant that legal theorists could be more open about their political convictions - in the sense of political and social theories - and those who had not supported the Marxist-Leninist orthodoxy could speak more openly about their preferred model of the political community and its conception of justice.

\section{The Historical Roots of Polish Jurisprudence}

The modern Polish state which emerged in 1918 was comprised of territories formerly belonging to the three great Central and Eastern European empires - the Russian, German and Austro-Hungarian. Polish jurists, including legal theorists and philosophers of law, received their legal education in the main academic centres of the respective Empires - St. Petersburg, Vienna and Berlin. The Kingdom of Galicia and Lodomeria (Galizien und Lodomerien) the multicultural Polish-Ukrainian-Jewish northernmost province of AustroHungary - boasted its own Polish-speaking universities in Lemberg (Lwów, Lvov) and Krakow, which were important centres of Polish legal scholarship up to World War I. The influence of Russian, Austrian and German, but also French ${ }^{4}$ legal scholarship upon the emergent, distinctly Polish jurisprudence meant that it became strongly imbued with continental legal thinking, with a special influence of French and German legal science. In other words, historical factors shaped the influences on Polish jurisprudence. ${ }^{5}$

4 The 'French connection' of Polish legal culture results from the fact that in the Kingdom of Poland (Tsarstvo Polskoie, Królestwo Polskie), which was part of the Russian Empire, it was French law which predominantly remained in force following its introduction in those territories during the Napoleonic wars (e.g. the code civil was introduced there in 1808). The continued application of French law meant that French case-law (of the Cour de cassation) and French doctrine remained an important point of reference for jurists in the Kingdom, despite its personal union with Russia (since 1815).

5 See also Tomasz Gizbert-Studnicki, Krzysztof Płeszka and Jan Woleński, 2oth-century Legal theory and Philosophy in Poland, in Enrico Pattaro and Corrado Roversi (eds.), A Treatise of Legal Philosophy and General Jurisprudence, Vol. 12: Legal Philosophy in the Twentieth Century: the Civil Law World (Springer, Dordrecht, 2016), 547-586. 
One can identify a number of eminent scholars in the world of jurisprudence whose research areas have inspired, and continue to inspire, today's Polish legal theory and philosophy of law. Amongst them one should mention above all Leon Petrażycki - the Russian-Polish jurist, philosopher and sociologist, who created a psychological theory of law. Petrażycki, as was mentioned above, is considered one of the founders of sociology of law and his works have had an immense impact both in Poland and abroad.

A second eminent scholar, whose concepts are an inspiration for Polish jurisprudence to this day, was Czesław Znamierowski - a jurist, philosopher and psychologist, whose concepts in the field legal theory and philosophy of law remained under the strong influence of Franz Brentano's descriptive psychology, as well as phenomenology.

A third scholar whose impact was significant was Bronisław Wróblewski a jurist and philosopher, and a specialist in the field of criminal law. Wróblewski's work on legal interpretation, including on legal language, has had a considerable impact on Polish legal theory.

A fourth important figure was Jerzy Lande - an outstanding jurist and legal theorist, whose legal concepts were heavily influenced by Leon Petrażycki.

These four scholars - Petrażycki, Znamierowski, Wróblewski and Lande can be seen as the founding fathers of $20^{\text {th }}$ century Polish jurisprudence. Each of them founded their own academic centres - the Warsaw school (Petrażycki), the Poznan school (Znamierowski), the Vilnius school (Wróblewski) and the Krakow school (Lande).

Apart from the aforementioned four founding fathers of Polish jurisprudence, one should also mention the impact of the Lvov-Warsaw school of philosophy, which shaped Polish analytical theory to a very large extent. ${ }^{6}$ Although the institutional unity of the Lvov-Warsaw school was significantly weakened after World War II, nonetheless the impact of the philosophical and logical concepts of Kazimierz Twardowski, Jan Łukasiewicz, Stanisław Leśniewski, Alfred Tarski, Tadeusz Czeżowski, Kazimierz Ajdukiewicz, Tadeusz Kotarbiński and many others was the direct source of many theoretical solutions and individual concepts created by Polish legal theorists.

Following World War II, a fourth centre of legal theory emerged in Łódź (the Łódź School) thanks to the fact that Professor Jerzy Wróblewski - a leading theorist both in Poland and internationally - became head of the State and Legal Theory Department (after the transformation of the political system in Poland: the Legal Theory and Legal Philosophy Department).

6 See Jan Woleński, Logic and Philosophy in the Lvov-Warsaw School (Kluwer Academic Publishers, Dordrecht, 1989). 


\section{Leading Personalities and Currents in Polish Jurisprudence during} the Socialist Period

\subsection{Leading Legal Theorists}

Polish jurisprudence of the socialist, post-War period, was greatly influenced by seven dominant intellectual leaders who can be considered as the successors of the professors described in the previous section. This 'heptarchy' included the following: Jerzy Wróblewski (Łódź), Józef Nowacki (Katowice), Jan Woleński (Krakow), Zygmunt Ziembiński (Poznań), Kazimierz Opałek (Krakow), Wiesław Lang (Toruń) and - somewhat of an outsider due to his remarkably anti-dogmatic and anti-analytical approaches - Stanisław Erhlich (Warsaw). These seven professors are considered to be the so-called first post-War generation of Polish legal theorists. This list should be completed with the inclusion of two leading sociologists of law - Maria Borucka-Arctowa (Krakow) and Adam Podgórecki (Warsaw).

The aforementioned legal scholars educated and shaped the views of a large group of Polish legal theorists of the so-called middle generation, which now plays an active role in shaping global jurisprudence, inter alia by participating in the bi-annual congresses of IVR - the International Association for Philosophy of Law and Social Philosophy. At present, there are 20 centres for the study of jurisprudence (legal theory, philosophy of law and sociology of law) at all the state-faculties of law, but also at certain non-public ones (notably at Koźmiński University, Łazarski University and swPS University, all three of which are in Warsaw). Some members of the middle generation of Polish jurisprudence - notably Adam Czarnota, Wojciech Sadurski (both in Australia), Zenon Bańkowski (Scotland), as well as Jerzy Kalinowski (France) and Aleksander Peczenik (Sweden) have contributed to the development of global jurisprudence by working at universities abroad.

\subsection{Main Topics of Research}

The main thematic sources of inspiration for Polish jurisprudence of the 2oth century can be grouped into four main groups: on the one hand, traditional currents of legal philosophy, inspired either by neo-Thomism or by Kantianism and neo-Kantianism; and on the other hand, two more recent currents, namely phenomenology and analytical philosophy. Crucially, there are many common assumptions that bind phenomenology and analytical philosophy together, especially their shared research focus, which expressed opposition to idealistic constructs. Both have had a strong and lasting impact upon Polish jurisprudence. The reasons for this are geographical: a Polish disciple of Edmund Husserl, Roman Ingarden, one of the most eminent representatives of 
phenomenology, naturally propagated this philosophical current in Poland. The same goes for the Lvov-Warsaw School and its impact.

However, it was mainly the analytical school in philosophy that was to dominate Polish jurisprudence, especially with regard to its adoption of atomism, logical empiricism and the approach of the Oxford school of ordinary language. Analytical legal theory unquestionably dominated Polish jurisprudence up to the end of actually existing socialism. In particular, the analysis of language as a carrier of meanings, performed from the perspective of logical semiotics, gave rise to a plethora of works. One of the reasons for this fact, apart from purely academic fashion, was also the fact that due to the domination of official Marxism-Leninism, new currents in political philosophy could not penetrate into Polish legal theory until $1989 .{ }^{7}$

In this place it is worth mentioning Hans Kelsen and his normativism, which clearly exerted a significant impact on legal theory and philosophy of law in Poland, although its greatest influence ended before World War II. In the post-war period, normativism was absorbed by the dominant analytical legal theory. Kazimierz Opałek - one of the most distinguished experts on Kelsen's theory and normativism in Poland and internationally - states:

In the period after 1956 the interests in normativism have continued. [...] Normativism is qualified as a 'one-dimension' theory of law. Furthermore, Polish legal theory is developing mainly in the analytical direction, convergent with that of pure theory of law. The opposition of 'Is' and 'Ought' in its logical aspect is accepted. ${ }^{8}$

\section{The Main Topics of Polish Jurisprudence Since 1945}

\subsection{The Domination of the Analytical Paradigm before 1989}

The topics analysed by Polish post-War legal theory encompassed such subjects as the theory of the legal norm, analysis of the notions of duty, obligation,

7 Michał Stambulski, "Polityczność w polskiej analitycznej teorii prawa. Zarys problematyki" [The Political in Polish Analytical Legal Theory: An Outline of the Issue], 3 Archiwum Filozofii Prawa i Filozofii Spotecznej (2018), 64-73, at 66.

8 Kazimierz Opałek, "Normatywizm w Polsce" [Normativism in Poland], 12 Krakowskie Studia Prawnicze (1989), 3-24, at 24. We would like to thank one of our anonymous Reviewers for the suggestion to include normativism, as distinct from analytical legal theory, among the currents of Polish jurisprudence in the 2oth century. We also agree with his or her suggestion that both analytical jurisprudence and Kelsenian normativism gave the impression that law is a phenomenon which can be grasped in an objective, neutral and 'scientific' manner. Therefore, they were used by Polish lawyers as a form of self-defence (even if a feeble one) against political pressures and the politicization of jurisprudence. 
'ought-to' and permission, analysis of the notion of subjective rights, analysis of legal and juristic language, deontic logic and the logic of norms, the theory of the legal system, the notion of the binding force of law, theories of the creation and application of law, theories of law and morality and the mutual relations between them, and the methodology of the legal sciences. The catalogue of topics reveals the predominantly analytical approach of Polish post-War jurisprudence. At around 1980 the array of subjects was gradually expanded, but it was only after the 1989 breakthrough that the analytical paradigm definitely lost its dominant position in Polish legal theory (see below, section 4.2).

One of the chief topics of theoretical legal scholarship of the socialist period was the theory of interpretation. Jerzy Wróblewski's first monograph on legal interpretation - Problems of the Theory of the Interpretation of People's Law, published in $1959,{ }^{9}$ inaugurated the popularity of this research topic in Polish legal theory. Wróblewski's two last monographs, The Judicial Application of Law (published in Poland in $1972^{10}$ and in English translation four years later ${ }^{11}$ ) and Understanding of the Law and its Interpretation (published in 1990), ${ }^{12}$ summarised the state of the academic debate in the Polish People's Republic and opened new directions of research.

Wróblewski's highly influential theory of legal interpretation, based on the principles of clara non sunt interpretanda and interpretatio cessat in claris ${ }^{13} \mathrm{can}$ be described as semantic and intensional. It was developed by other legal theorists in Poland and abroad, and has had a great impact upon the Polish practice of legal interpretation, especially influencing the case-law. Wróblewski's concept of 'directives of interpretation' became an essential tool used in the motives of judicial and administrative decisions.

An alternative theory of interpretation began to be developed from the 1970s in the Poznan School, referring to itself as the 'derivational' (or 'derivatory') theory of interpretation, ${ }^{14}$ as opposed to Wróblewski's 'clarificatio-nal

Jerzy Wróblewski, Zagadnienia teorii wykładni prawa ludowego [Problems of the Theory of the Interpretation of People's Law] (Państwowe Wydawnictwo Naukowe, Warszawa, 1959).

10 Jerzy Wróblewski, Sadowe stosowanie prawa [The Judicial Application of Law] (1st ed., Państwowe Wydawnictwo Naukowe, Warsaw, 1972); idem, Sadowe stosowanie prawa (2nd ed., Państwowe Wydawnictwo Naukowe, Warsaw, 1988).

11 Jerzy Wróblewski, The Judicial Application of Law (Kluwer Academic Publishers, Dordrecht, 1992, edited by Zenon Bankowski and Neil MacCormick).

12 Jerzy Wróblewski, Rozumienie prawa i jego wyktadnia [Understanding of the Law and its Interpretation] (Ossolineum, Wrocław, 1990).

13 Meaning, respectively, that 'clear (texts) shall not be interpreted' and 'interpretation shall cease once clarity is achieved'.

14 See e.g. Michał Białkowski, "The Derivative Concept of Legal Interpretation," 10(2) Studia Prawa Publicznego (2015), 153-165. 
theory of interpretation. ${ }^{\prime 5}$ The theory was further refined in the works of Maciej Zieliński, ${ }^{16}$ an unquestionable authority within the Poznań School of legal theory on the theory of legal interpretation.

The traditional approach of Polish analytical jurisprudence has been continued after 1989, especially in the Poznań-Szczecin school and at the Marie Curie-Skłodowska University in Lublin, where Leszek Leszczyński developed his validational-semantic concept of legal interpretation, ${ }^{17}$ whereas most other centres of legal theory embraced, by and large, new currents. However, individual representatives of traditional, analytical legal theory continue to be active in all Polish universities.

\subsection{New Currents after 1989}

The end of actually existing socialism and the demise of the officially upheld ideological hegemony of orthodox Marxism-Leninism opened up Polish jurisprudence to a host of new currents, hitherto absent or underrepresented in comparison to the liberal West. These can be grouped into seven main subjectmatter areas: naturalistic currents, including law and economics and the application of cognitive science to law (section 4.2.1), legal ethics (section 4.2.2), new currents in the philosophy of interpretation (section 4.2.3), postmodern and critical jurisprudence (section 4.2.4), and transitional justice (4.2.5).

Section 4.2.6 is devoted to juriscentrism, an original and highly innovative Polish jurisprudential current, which was intended as a meta-analytical response to the postmodern critique of law, and in section 4.2.7 we will mention a slightly isolated movement in Polish legal philosophy, namely the phenomenology of law.

\subsubsection{Naturalistic Currents}

Following the transformation of 1989 and the dismantling of the official Marxist-Leninist ideological limits, Polish theorists and philosophers of law

15 On the controversy, see e.g. Andrzej Grabowski, "Clara Non Sunt Interpretanda vs. Omnia Sunt Interpretanda: A Never-Ending Controversy in Polish Legal Theory?," 27 Revus (2015), 67-97.

16 For a compact presentation of the theory in the form of ready-to-use canons of interpretation, see Maciej Zieliński, Wykładnia prawa. Zasady - reguty - wskazówki [Legal Interpretation: Principles - Rules - Directives] ( $7^{\text {th }}$ ed., Wolters Kluwer, Warsaw, 2017).

17 See e.g. Leszek Leszczyński, Stosowanie generalnych klauzul odsytajacych [The Application of General Referring Clauses] (Kantor Wydawniczy Zakamycze, Krakow, 2001); idem, Podejmowanie decyzji prawnych. Tworzenie i stosowanie prawa [Legal Decision-Making: Creation and Application of Law] (Wydawnictwo WSZiA, Zamość, 2003); Leszek Leszczyński, Bartosz Wojciechowski and Marek Zirk-Sadowski, Wyktadnia w prawie administracyjnym [Interpretation in Administrative Law] (C.H. Beck, Warsaw, 2012). 
could more broadly explore the contemporary currents of Western jurisprudence. One area of particular interest especially for the Krakow centre of jurisprudence at the Jagiellonian University (and to some extent for the Łódź school) have been naturalistic currents in legal philosophy which - to put it simply - imply the use of methods of economics and the natural sciences to study legal phenomena. Hence the popularity of law and economics ${ }^{18}$ in Poland, legal cognitivism (including the study of legal metaphors ${ }^{19}$ ) and other similar currents, broadly referred to as 'legal naturalism'. ${ }^{20}$ The main representatives of this approach include Tomasz Pietrzykowski, ${ }^{21}$ Jerzy Stelmach, Bartosz Brożek, Wojciech Załuski and Mariusz J. Golecki. ${ }^{22}$

\subsubsection{Legal Ethics}

An important field of philosophy of law which has virtually emerged after 1989 is legal ethics, understood as a field of philosophical enquiry, and not only a dogmatic analysis of deontological codes of the legal professions. Leading scholars in the field include Tomasz Pietrzykowski, ${ }^{23}$ Paweł Skuczyński, ${ }^{24}$

18 Rafał T. Stroiński, "Ekonomiczna analiza prawa, czyli w poszukiwaniu efektywności" [Economic Analysis of Law or in Search of Effectiveness], 3 Kwartalnik Prawa Prywatnego (2002), 549-583; Jarosław Bełdowski and Katarzyna Metelska-Szaniawska, "Law \& Economics - geneza i charakterystyka ekonomicznej analizy prawa," [Law \& Economics - Genesis and Characterization of Economic Analysis of Law] 10 Bank i Kredyt (2007), 51-69; Jerzy Stelmach, Bartosz Brożek and Wojciech Załuski, Dziesięć wykładów o ekonomii prawa [Ten Lectures on the Economy of Law] (Oficyna, Warsaw, 2007).

19 Rafał Augustyn, Iwona Witczak-Plisiecka and Sylwia Wojtczak, Metafory konceptualne jako narzędzia rozumowania i poznania prawniczego [Conceptual Metaphors as Tools of Legal Reasoning and Cognition] (Wolters Kluwer, Warsaw, 2017).

20 Jerzy Stelmach, Bartosz Brożek, Łukasz Kurek and Katarzyna Eliasz (eds.) Naturalizm prawniczy. Interpretacje [Legal Naturalism: Intepretations] (LEX, Warsaw, 2015).

21 Tomasz Pietrzykowski, Intuicja prawnicza. W stronę zewnętrznej integracji teorii prawa [Juristic Intuition: Towards the External Integration of Legal Theory] (Difin, Warsaw, 2012).

22 Mariusz J. Golecki, Między pewnością a efektywnością: Marginalizm instytucjonalny wobec prawotwórczego stosowania prawa [Between Certainty and Efficiency: Institutional Marginalism and the Creative Application of Law] (Warsaw, LEX, 2011).

23 Tomasz Pietrzykowski, Etyczne problemy prawa [Ethical Problems of Law] (LexisNexis, Warsaw, 2011).

24 Paweł Skuczyński, Status etyki prawniczej [The Status of Legal Ethics] (LexisNexis, Warsaw, 2010). An English translation was also published: idem, The Status of Legal Ethics (Peter Lang, Berlin, 2013). 
Przemysław Kaczmarek ${ }^{25}$ and Marcin Pieniążek. ${ }^{26}$ The topics analysed by Polish legal ethics include, above all, the ethics of judges, ${ }^{27}$ attorneys and lawyers of the State Treasury Solicitor's Office, ${ }^{28}$ but also other ethical questions, such as the legal status of animals. ${ }^{29}$ An emergent topic of inquiry in Polish legal philosophy is the ethics of interpretation. ${ }^{30}$

\subsubsection{Philosophy of Interpretation}

The evergreen topic of Polish legal theory of the post-War period - legal interpretation - has been significantly enriched by the post-1989 jurisprudential discourse which supplemented the analytical theory of legal interpretation with a rich philosophy of legal interpretation, especially within such currents as legal hermeneutics and communicative theories of law, as well as the

25 Przemysław Kaczmarek, Tożsamość prawnika jako wykonawcy roli zawodowej [Identity of a Lawyer as a Professional Role Perfomer] (LexisNexis, Warsaw, 2014). Kaczmarek applies sociological approaches to legal ethics, finding particular inspiration in the work of the late Zygmunt Bauman.

26 Marcin Pieniążek, Etyka sytuacyjna prawnika [Situation Ethics of a Lawyer] (LexisNexis, Warsaw, 2008). Pieniążek's philosophical inspiration include Max Scheler, Nikolai Hartmann and Józef Tischner, and his main assumption is that the legal corporation is phenomenological communicative community.

27 Paweł Skuczyński and Marek Zirk-Sadowski, "Dwa wymiary etyki zawodowej sędziów" [Two Dimensions of a Judge's Professional Ethics], 1 Krajowa Rada Sadownictwa (2012), $12-22$.

28 See e.g. Bronisław Sitek, "A state and the protection of its interests. Advocatus fisci vs State Treasury Solicitors' Office," 2 Journal of Modern Science (2017), 49-6o; idem, "Deontologia prawnicza w praktyce advocatus fisci i radcy Prokuratorii Generalnej Skarbu Państwa” [Lawyers' Deontology in the Practice of an Advocatus Fisci and a Councillor of the State Treasury Solicitor's Office], in Krzysztof Amielańczyk et al. (eds.), Prawo karne i polityka w prawie rzymskim [Criminal Law and Politics in Roman Law] (UMCS, Lublin, 2015), $145^{-157}$

29 See e.g. Joanna Helios and Wioletta Jedlecka, "Okrucieństwo wobec zwierząt z punktu widzenia psychologii i filozofii: zarys problem," [Cruelty Towards Animals from the Point of View of Psychology and Philosophy: An Outline of the Issue], 108 Przeglad Prawa $i$ Administracji (2017), 31-44; eaedem, Wspótczesne oblicza przemocy. Zagadnienia wybrane [Contemporary Forms of Violence: Selected Issues] (Prawnicza i Ekonomiczna Biblioteka Cyfrowa, Wrocław, 2017), 123ff; Pietrzykowski, op.cit., 21off.

30 Paweł Skuczyński, "Etyka wykładni prawa? Uwagi na tle książki Susanny Lindroos-Hovinheimo pt. Justice and the Ethics of Legal Interpretation" [Ethics of Legal Interpretation? Remarks Against the Background of the Book by Susannya Lindroos-Hovinheimo entitled Justice and the Ethics of Legal Interpretation] in Mikołaj Hermann, Sebastian Sykuna (eds.), Wyktadnia prawa. Tradycja i perspektywy [Legal Interpretation: Tradition and Perspectives] (C.H. Beck, Warszawa, 2016); Rafał Mańko, W stronę krytycznej filozofii orzekania. Polityczność, etyka, legitymizacja [Towards a Critical Philosophy of Adjudication: The Political, Ethics and Legitimacy] (Wydawnictwo Uniwersytetu Łódzkiego, Łódź, 2018), 171-220, 266-268. 
aforementioned emergent ethics of interpretation. Legal hermeneutics in the Polish philosophy of law has been developed especially by Jerzy Stelmach ${ }^{31}$ (Krakow), Henryk Leszczyna ${ }^{32}$ and Marek Zirk-Sadowski ${ }^{33}$ (Łódź). In this context, one should also mention the highly original and innovative conception of 'stratified interpretation of legal texts' (poziomowa interpretacja tekstu prawnego) put forward in the 1990 s by Ryszard Sarkowicz, ${ }^{34}$ whereby within a legal text various strata (layers, levels) are identified, each of which should be subjected to different interpretive methods aiming at different purposes and yielding different results. Both legal hermeneutics and Sarkowicz's concept of stratified interpretation bring to the fore the cultural dimension of law, which was somewhat downplayed in classical analytical legal theory. Concerning communicative theories of law and legal interpretation, one should mention above all the late Lech Morawski (1949-2017), who is credited not only with 'inviting' postmodernism to Poland (see section 4.2.4), but who also engaged in dialogue with the theories of Jürgen Habermas, Niklas Luhmann and Gunther Teubner. ${ }^{35}$ Finally, the picture of new currents in Polish philosophy of interpretation would not be complete without mentioning the growing interest in pragmatist theories, including the concepts of Stanley Fish, ${ }^{36}$ as part of a broader context of 'post-analytical' jurisprudence, developed especially in the Wrocław centre of legal theory. ${ }^{37}$

31 Jerzy Stelmach, Die hermeneutische Auffasung der Rechtsphilosophie (Gremer, Ebelsbach, 1991).

32 Henryk Leszczyna, Hermeneutyka prawnicza. Rozumienie i interpretacja tekstu prawnego [Legal Hermeneutics: The Understanding and Interpretation of a Legal Text] (Oficyna Naukowa, Warsaw, 1996).

33 Marek Zirk-Sadowski, Prawo a uczestniczenie w kulturze [Law and Participation in Culture] (Wydawnictwo Uniwersytetu Łódzkiego, Łódź, 1998).

34 Ryszard Sarkowicz, Poziomowa interpretacja tekstu prawnego [Stratified Interpretation of Legal Text] (Prace Habilitacyjne UJ, Krakow, 1995).

35 See especially Lech Morawski, Gtówne problemy wspótczesnej filozofii prawa. Prawo w toku przemian [The Main Problems of Contemporary Legal Philosophy: Law in the Course of Transformation] (Państwowe Wydawnictwo Naukowe, Warsaw, 1999), 78-124. Morawski confronted the systems-theory and communication theory approaches as two forms of treating 'law as a conversation'.

36 See e.g. Jakub Łakomy, "Polityczność (teorii) wykładni prawa. Perspektywa neopragmatyzmu Stanleya Fisha" [The Political Character of (the Theory of) Legal Interpretation: The Perspective of Stanley Fish's Neopragmatism], 3 Archiwum Filozofii Prawa i Filozofii Spotecznej (2018), 24-37; idem, "The Space of the Political in Legal Interpretation (Some Remarks on The Dworkin-Fish Debate)," in Paulina Bieś-Srokosz, Rafał Mańko and Jacek Srokosz (eds.), Law, Space and the Political: an East-West Perspective (Stanisław Podobiński Publishing House, Częstochowa, 2019), 127-138.

37 Andrzej Bator and Zbigniew Pulka (eds.), A Post-Analytical Approach to Philosophy and Theory of Law (Peter Lang, Berlin, 2019). 


\subsubsection{Postmodern and Critical Currents}

As Adam Sulikowski has pointed out, during the socialist period Polish jurisprudence was officially critical (towards Western, bourgeois law), but had to be programmatically apologetic about socialist law, which was - for obvious political reasons - immune from critique. ${ }^{38}$ Hence, despite the presence of certain critical tools in Polish jurisprudence, critical legal theory could not emerge since the critique of the local law was simply foreclosed. It was only after 1989 that both critical and postmodern currents could enter Polish jurisprudence.

The first area of impact was the reception of so-called 'French Theory', i.e. the works of three French classics of postmodern thought - Michel Foucault, Jacques Derrida and Gilles Deleuze. Whilst their impact upon jurisprudence (and beyond) had been strongly felt in the West already from the 1980 s, in Poland their thought began to exert an influence only from the late 1990s, i.e. with a delay of two decades, caused inter alia by the political situation under actually existing socialism, where heterodox Marxism and postmodernism were treated with great suspicion by the hegemonic ideology of official Marxism-Leninism.

The first Polish jurisprudential work on law and postmodernism was authored in 1999 by Bartosz Wojciechowski, ${ }^{39}$ but the doors to postmodernism were only officially thrown wide-open two years later by Lech Morawski in his programmatic monograph-manifesto entitled What Can Legal Scholarship Gain from Postmodernism. ${ }^{40}$ The early 2000 s brought a whole plethora of writings on the subject, especially by Sulikowski, ${ }^{41}$ Wojciechowski and Sławomir

38 Adam Sulikowski, "Afirmatywna amnezja i konserwatywni crits. Kilka uwag o kondycji krytycznej myśli prawniczej w Europie Środkowej i Wschodniej” [Affirmative Amnesia and Conservative Crits: Some Remarks on the Condition of Critical Legal Thought in Central and Eastern Europe], 1 Archiwum Filozofii Prawa i Filozofii Spotecznej (2014), 77-87.

Bartosz Wojciechowski, "Dekonstrukcja między prawem a sprawiedliwością" [Deconstruction Between Law and Justice], in Leszek Leszczyński (ed.), Zmiany spoteczne a zmiany w prawie [Social Change and Legal Change] (UMCS, Lublin, 1999), 305-315.

$40 \quad$ Lech Morawski, Co może dać nauce prawa postmodernizm? (TNOiK, Toruń, 2001).

41 Adam Sulikowski, "Nowoczesność i ponowoczesność w pojmowaniu prawa" [Modernity and Postmodernity in Understanding the Law], 2 Zeszyty Naukowe Watbrzyskiej Wyższej Szkoty Zarządzania i Przedsiębiorczości (2006), 119-127; idem, "O ponowoczesnej teorii prawa" [On Postmodern Legal Theory], in Adam Sulikowski (ed.), W poszukiwaniu podstaw prawa [In Search for Law's Foundations] (Wydawnictwo Uniwersytetu Wrocławskiego, Wrocław, 2006), 243-258; idem, "Poststrukturalistyczne pojmowanie prawa w myśli M. Foucaulta" [The Post-Structuralist Understanding of Law in the Thought of M. Foucault], 1 Zeszyty Naukowe Watbrzyskiej Wyższej Szkoty Zarzadzania i Przedsiębiorczości (2007), 174-182; idem, "Derridiańska koncepcja prawa" [The Derridian Concept of Law], 1 Zeszyty Naukowe Watbrzyskiej Wyższej Szkoty Zarzadzania i Przedsiębiorczości (2007), 166-173; idem, "O możliwościach postmodernizacji nauki 
Oliwniak. ${ }^{42}$ However, it was Sulikowski who became the main representative of critical legal theory in Poland, with his ground-breaking works on postmodernism and constitutionalism, ${ }^{43}$ and jurisprudence and posthumanism, ${ }^{44}$ setting the trend not only in Polish, but more generally Central European critical legal studies. ${ }^{45} \mathrm{~A}$ symbolic recognition of this role was the organisation of the 3oth Critical Legal Conference - the annual gathering of English-speaking critical legal scholars ${ }^{46}$ - at the University of Wrocław. ${ }^{47}$

prawa konstytucyjnego" [On the Possibilities of Postmodernising the Science of Constitutional Law], 12 Państwo i Prawo (2010), 3-16; idem, "Opresywność pozytywizmu prawnego i jego postmodernistyczna krytyka" [The Oppressiveness of Legal Positivism and Its Postmodern Crtiique], in Przemyław Kaczmarek and Łukasz Machaj (eds.), Pozytywizm prawniczy i szkota prawa natury - tradycje sporu ijego wspótczesne implikacje [Legal Positivism and Natural Law School - Tradition of Dispute and its Contemporary Implications] (Prawnicza i Ekonomiczna Biblioteka Cyfrowa, Wrocław, 2010), 28-35.

42 Sławomir Oliwniak, "Transgresja, dyskurs, prawo w ujęciu Michela Foucaulta" [Transgression, Disourse and Law According to Michel Foucault], in Jerzy Stelmach (ed.), Filozofia prawa wobec globalizmu [Legal Philosophy Regarding Globalism] (Wydawnictwo Uniwersytetu Jagiellońskiego, Krakow, 2003), 207-221; idem, "Michel Foucault a potrzeba nauczania filozofii prawa" [Michel Foucault and the Need to Teach Philosophy of Law], in Maria Szyszkowska (ed.), Filozofia prawa w życiu i nauczaniu [Philosophy of Law in Life and Teaching] (Temida 2, Białystok, 2004), 68-84; idem, "Etyka siebie. Dokończony projekt oświecenia Michela Foucaulta” [Ethics of the Self: Michel Foucault's Completed Project of Enlightenment], in Tomasz Kozłowski and Karol Kuźmicz (eds.), Człowiek wobec systemów wartości [The Human Being and Value Systems] (Temida 2, Białystok, 2006), 44-55; idem, "Biopolitics and the Rule of Law," 32 Studies in Logic, Grammar and Rhetoric (2009), 33-48. Oliwniak, as one of the very few Polish philosophers of law, also referred to the works of Giorgio Agamben - see e.g. Sławomir Oliwniak, "Giorgio Agamben: biopolityka i 'pusta' forma prawa” [Giorgio Agamben: Biopolitics and the 'Empty' Legal Form], in Wiesław Staśkiewicz and Tomasz Stawecki (eds.), Dyskrecjonalność w prawie [Discresion in Law] (LexisNexis, Warsaw, 2010), 540-549; idem, "Foucault and Agamben: Law As Inclusive/Exclusive Discourse," 39 Studies in Logic, Grammar and Rhetoric (2011), 49-62.

43 Adam Sulikowski, Konstytucjonalizm a nowoczesność: dyskurs konstytucyjny wobec tryumfu i kryzysu moderny [Constitutionalism and Modernity: Constitutional Discourse Towards the Triumph and Crisis of Modernity] (Wydawnictwo Uniwersytetu Wrocławskiego - Złota Seria, Wrocław, 2012).

44 Adam Sulikowski, Posthumanizm a prawoznawstwo [Posthumanism and Legal Scholarship] (Wydawnictwo Uniwersytetu Opolskiego, Opole, 2013).

45 Rafał Mańko, "Critical Legal Theory in Central and Eastern Europe: In Search of Method," 89 Folia Iuridica (2019), 5-14, 6. Cf. Rafał Mańko, Cosmin Cercel and Adam Sulikowski (eds.), Law and Critique in Central Europe: Questioning the Past, Resisting the Present (Counterpress, Oxford, 2016).

46 Costas Douzinas, "A Short History of the British Critical Legal Conference or, the Responsibility of the Critic," 25(2) Law and Critique (2014), 187-198.

47 Wojciech Zomerski, "The 3oth Critical Legal Conference on 'Law, Space and the Political,' University of Wrocław, Faculty of Law, Administration and Economics, 3-5 September 2015," 2 Archiwum Filozofii Prawa i Filozofi Spotecznej (2016), 85-88. For a selection of 
Sub-fields of postmodern and critical legal theory, gradually developing in Polish jurisprudence, include the study of such areas as law and literature, ${ }^{48}$ law and ideology, ${ }^{49}$ law and (neo)colonial theory/theories of peripherality, ${ }^{50}$ as well as feminist jurisprudence. ${ }^{51}$ There is a noticeably growing influence of

papers inspired by that conference see Paulina Bieś-Srokosz, Rafał Mańko and Jacek Srokosz (eds.), op.cit. note 36 .

48 See e.g. Adam Sulikowski, "Literary fiction in legal dogmatics in continental European constitutional law," 432 Acta Universitatis Brunensis. Iuridica (2012), 45-52. The topic of law and literature, a classical topos of critical legal theory, is only now gaining popularity in Poland. However, it has been flourishing in the neighboring Czech Republic for more than a decade.

49 The topic of 'law and ideology' was analyzed during a series of five consecutive annual workshops, held between 2014 and 2017 in Wrocław, Sarajevo, Tbilisi, Timişoara and Vilnius. Selected papers from the first and second workshop were published in a special issue of the Wroclaw Review of Law, Administration and Economics volume 5, issue 1 (2015). The workshops were succeeded by the Critico-Juridical Symposia, first of which was held in Opole in 2018. Its papers have been published in a special issue of the journal Folia Iuridica (vol. 89, 2019). The $2^{\text {nd }}$ Critico-Juridical Symposium was held in Krakow in 2019, and the $3^{\text {rd }}$ Symposium will take place at the West University, Timişoara.

5o For attempts to apply Immanuel Wallerstein's theories of peripherality to a sociological analysis of the legal field in Poland see recently Hanna Dębska, "Prawo jako pole (ujęcie modelowe)" [Law as a Field (Model Approach)], g Państwo i Prawo (2016), 36-53; eadem, "Strategia wielopozycyjności w półperyferyjnym polu prawnym. Homo academicus na rynku" [Multiposition Strategy in a Semiperipheral Legal Field: Homo Academicus on the Market], in Tomasz Zarycki (ed.) Polska jako peryferie [Poland as a Periphery] (Scholar, Warsaw, 2016), 221-240. See also Rafał Mańko, "Legal Transfers in Europe Today: Still 'Modernisation Through Transfer'?," in Paulina Bieś-Srokosz, Jacek Srokosz and Ewelina Żelasko-Makowska (eds.), Mutual Interaction Between Contemporary Systems and Branches of Law in European Countries (Podobiński Publishing, Częstochowa, 2017), 139-155; Rafał Mańko, Martin Škop and Markéta Štěpáníková, "Carving out Central Europe as a space of legal culture: a way out of peripherality?" 6(2) Wroclaw Review of Law, Administration and Economics (2018), 3-28; Rafał Mańko, "Delimiting Central Europe as a Juridical Space: A Preliminary Exercise in Critical Legal Geography," 89 Folia Iuridica (2019), 63-79. The problem is noticed also by Western observers, see e.g. Hans-W. Micklitz, "Prologue: The Westernisation of the East and the Easternisation of the West," in Michal Bobek (ed.), Central European Judges Under the European Influence: The Transformative Power of the EU Revisited (Hart Publishing, Oxford, 2015), 1-12.

51 See e.g. Hanna Dębska, "Płeć i władza. Kobiety w Trybunale Konstytucyjnym" [Gender and Power: Women in the Constitutional Court], 22 Studia Podlaskie (2014), 91-111; Lidia Rodak, "Structural Violence and Its Gender Dimension in Polish Law," in Rafał Mańko et al. (eds.), op.cit. note 45, 131-153; Hanna Dębska and Tomasz Warczok, "The Social Construction of Feminity in the Discourse of the Polish Constitutional Court," in Mańko et al. (eds.), op.cit. note 45, 106-130; Wioletta Jedlecka and Joanna Helios, Wptyw feminizmu na sytuacje spoteczno-prawna kobiet [The Impact of Feminism on the Socio-Legal Situation of Women] (Prawnicza i Ekonomiczna Biblioteka Cyfrowa, Wrocław, 2016); Adam Sulikowski, "Prawo i płeć: kilka uwag o potencjale krytycznym feministycznej jurysprudencji” 
critical sociology (inspired by the legacy of Pierre Bourdieu) and critical discourse analysis (inspired by the works of Norman Fairclough), ${ }^{52}$ which have been successfully employed especially by Hanna Dębska and Tomasz Warczok and seem to be a promising paradigm for invigorating critical legal theory from an empirical perspective. ${ }^{53}$ The concept of 'the political', in the sense used by Chantal Mouffe, has been evoked to propose a 'political theory of law, ${ }^{54}$ conceived as an analysis of the juridical phenomenon through the lens of the political. Finally, one should mention a special form of critical legal studies, based on an empirically grounded realist jurisprudence, advanced by Paweł Chmielnicki and a group of researchers following him. ${ }^{55}$ Chmielnicki's method situated at the interstices of legal theory and socio-legal studies - is based on analysing the empirically verifiable interests involved in legislative and judicial legal developments, which often leads to questioning the official narrative about the beneficiaries of legal innovations (for instance, a piece of legislation is presented as benefiting consumers, whereas in fact it mainly benefits the banking sector $\left.{ }^{56}\right)$.

[Law and Gender: Some Remarks on the Critical Potential of Feminist Jurisprudence], 8 Wroctawsko-Lwowskie Zeszyty Prawnicze (2017), 85-101.

52 Adam Sulikowski, "Perspektywy zastosowań metod Krytycznej Analizy Dyskursu w badaniach nad prawem. Kilka uwag" [The Perspectives of Applying the Critical Discourse Analysis Methods to Legal Research: Some Remarks], 8 Studia Erasmiana Wratislawiensia (2014), 99-111.

53 Hanna Dębska, Wtadza, symbol, prawo. Spoteczne tworzenie Trybunatu Konstytucyjnego [Power, Symbol, Law: The Social Construction of the Constitutional Court] (Wydawnictwo Sejmowe, Warszawa, 2015); Hanna Dębska and Tomasz Warczok, "Sacred Law and Profane Politics. The Symbolic Construction of the Constitutional Tribunal," 4 Polish Sociological Review (2014), 465-478.

54 Michał Paździora and Michał Stambulski, "Co może dać nauce prawa polityczność? Przyczynek do dalszych badań," [What Can the Political Bring to Legal Science? Notes Towards an Investigation] 1 Archiwum Filozofii Prawa i Filozofii Spotecznej (2014), 55-66. See also Adam Sulikowski, Rafał Mańko and Jakub Łakomy, "Polityczność prawa i ogólnej refleksji nad prawem: wprowadzenie" [The Political Character of Law and General Jurisprudence: An Introduction], 3 Archiwum Filozofii Prawa i Filozofii Spotecznej (2018), 5-9.

55 Paweł Chmielnicki "The Research Method of Association for the Research on Sources and Functions of Law," 3 Przeglad Prawa Publicznego (2015), 95-105.

$5^{6}$ Paweł Chmielnicki "Źródła i efektywność regulacji dotyczących nabycia lokalu lub domu od dewelopera. Ocena wstępna" [Sources and Effectiveness of Legal Regulations Concerning Acquisition of Housing Unit from a Developer. Preliminary Assessment], 7-8 Przeglad Prawa Publicznego (2014), 141-156; idem (ed.), Nabycie lokalu lub domu od dewelopera. Wyktadnia przepisów i efekty ich stosowania [The Acquisition of Housing Unit from a Developer. Interpretation of Legal Regulation and Consequences its Application] (Difin, Warsaw, 2014). 


\subsubsection{Transitional Justice}

Owing to the fact that Poland underwent a profound socio-economic and political transformation in 1989, the emergence of a burgeoning field of transitional justice studies should have been taken for granted. However, this has not been the case and the scope of the field seems limited. In fact, the most prominent scholars of transitional justice in Poland include three Polish emigre lawyers in Australia: Adam Czarnota, Wojciech Krygier and Wojciech Sadurski, who have made immense contributions to the field, not only concerning the Polish context. ${ }^{57}$ A topic belonging to transitional justice sensu largo is the issue of 'legal survivals,' i.e. legal institutions of the socialist period which have continued to exist in the legal system following the transformation, ${ }^{58}$ including survivals in the field of legal culture, in particular - judicial mentality. ${ }^{59}$

\subsubsection{Juriscentrism}

In 2002, with the publication of Artur Kozak's monograph on The Limits of Jurists' Discretionary Power, a new and highly original current of jurisprudence was born - juriscentrism. ${ }^{60}$ It can be described as a 'meta-analytical' ${ }^{61}$ type of jurisprudence, aimed at bridging the gap between traditional analytical jurisprudence on the one hand, and critical and postmodern currents, on the other. Juriscentrism is aimed at defending the legitimacy of lawyers' power in society vis-a-vis postmodern critique. As such, its emergence in Poland only a decade after the transformation and opening towards Western legal thought was, in itself, unique. Kozak's premature death in 2009 prevented him from completing the juriscentrist theoretical project, but it continues to inspire Polish jurisprudence and, perhaps, will find its continuation one day.

57 See especially Adam Czarnota, Martin Krygier and Wojciech Sadurski (eds.), Rethinking the Rule of Law After Communism (Central European University Press, Budapest, 2005); Wojciech Sadurski, Adam Czarnota and Martin Krygier (eds.), Spreading Democracy and the Rule of Law? The Impact of EU Enlargement for the Rule of Law, Democracy and Constitutionalism in Post-Communist Legal Orders (Springer, Dordrecht, 2006); Adam Czarnota, "Rule of Law as an Outcome of Crisis. Central-Eastern European Experiences 27 Years after the Breakthrough," 8 Hague Journal on the Rule of Law (2016), 311-321.

58 See e.g. Rafał Mańko "Demons of the Past"? Legal Survivals of the Socialist Legal Tradition in Contemporary Polish Private Law," in Mańko et al. (eds.), op.cit. note 45, 66-89.

59 See e.g. Marek Zirk-Sadowski, "Transformation and Integration of Legal Cultures and Discourses-Poland," in Sadurski et al. (eds.), Spreading, op.cit. note 57, 299-311; Adam Czarnota, "Rule of Law and Functions and Dysfunctions of Judicial Culture in CentralEastern Europe. Reflections After 25 Years from Breakthrough," in Anna Piszcz (ed.), Court Culture: Contemporary Problems (Temida2, Białystok, 2014), 32-42.

6o For a broader discussion see Rafał Mańko, "Artur Kozak's Juriscentrist Concept of Law: A Central European Legal Innovation", in this issue.

61 The term was suggested to us by Dr Maciej Pichlak (Artur Kozak's doctoral student). 


\subsubsection{The Phenomenology of Law}

Following the publication, in 1989, of a critical edition of the works of Adolf Reinach $^{62}$ (one of the most prominent phenomenologists and surely the most remarkable legal phenomenologist), the phenomenology of law became a matter of serious interest not only for West-European and North American legal philosophers but also for Polish ones. A new edition of Reinach's fundamental monograph on legal phenomenology, i.e. Die apriorischen Grundlagen des bürgerlichen Rechtes [The A priori Foundations of Civil Law] caused renewed interest in the most basic questions of legal philosophy concerning the nature and concept of law, the logical value of legal norms, the relationship between the concepts of law and morality, the ontology of positive law and so on. In the Polish philosophy of law these issues have been studied by Tomasz Bekrycht (a legal phenomenologist from the Łódź school). In his works he has applied the phenomenological method, which exposes equivocations concerning the aforementioned subjects in possibly the most precise way. He analysed the subject, i.e. law (as a general idea) and positive law from the perspective of existential and ontological questions (existence and mode of existence), formal and ontological questions, as well as material and ontological questions. Finally, in his ontological (eidetic) analyses he determined the ultimate conditions of the existence of law and positive law, their form and esse $\left(\right.$ eidos). ${ }^{63}$

As this brief and selective overview has shown, Polish jurisprudence of the post-War period has been occupied with a rich array of topics. A particularly favourite one in the socialist period was legal interpretation and, more broadly,

62 Adolf Reinach, Sämtliche Werke. Textkritische Ausgabe in 2 Bänden [Complete Works. Critical Edition in 2 Volumes] (Philosophia Verlag, Munich, 1989, edited by Karl Schumann and Barry Smith).

63 See e.g. Tomasz Bekrycht, Transcendentalna filozofia prawa. Ozewnętrznymobowiazywaniu i uzasadnieniu istnienia prawa [Transcendental Legal Philosophy. On External Validity and the Justification of Law's Existence] (Wydawnictwo Uniwersytetu Łódzkiego, Łódź, 2015); idem, "O wartości logicznej normy prawnej" [About Logical Value of Legal Norm], 84 Studia Prawno-Ekonomiczne (2011), 11-38; idem, "On the Possibility of Justifying the Idea of Human Rights," in Marek Zirk-Sadowski, Bartosz Wojciechowski and Karolina Cern (eds.), Towards Recognition of Minority Groups. Legal and Communication Strategies (Ashgate, Farnham, 2014), 51-59; idem, "Metafizyka pozytywizmu prawniczego w świetle fenomenologii prawa" [The Metaphysics of Legal Positivism in the Light of Phenomenology of Law], 1 AVANT (2018), 21-29. 
an analytical study of legal language, legal norms and legal concepts. The demise of actually existing socialism in 1989 significantly broadened the scope of interests of Polish jurisprudence, expanding it both towards naturalistic currents, directed at the application of the natural sciences to juridical phenomena, as well as towards more humanistic approaches, including legal ethics, critical and postmodern legal theories and, finally, the original and unfinished project of juriscentrism.

The perspective of the last decade of Polish legal theory and philosophy of law allows two observations to be formulated. Firstly, Polish jurisprudence has, by and large, preserved a continuity of tradition, both in legal research and legal education, despite the deep socio-economic and political transformation of 1989. This was possible thanks to the high intellectual potential of Polish legal theorists and philosophers of law and their permanent participation in the global discourse of jurisprudence. Secondly, recent years have seen a period of systemic changes in higher education, which to a large extent is concerned with changes in the structure of academic activity, leading to an even more intensive participation of Polish scholars in the international discourse of legal theory, including its most recent currents. Of course, the phenomenon of globalization and systemic changes was not a condicio sine qua non of the participation of Polish jurisprudence in the global discourse (where it has always been strongly present), but the opening of the system of higher education to research projects allows for an even closer cooperation with many centres of legal theory and philosophy of law in the world.

The present special issue of the Review of Central and East European Law presents a subjective selection of the main topics of Polish post-War jurisprudence which we have judged to be most significant. Our focus has been mainly on the socialist period (1945-1989), which continues to exert an immense influence upon contemporary Polish legal theory. Special attention has been given to the legacy of Professor Jerzy Wróblewski - undoubtedly the most well-known Polish legal theorist, who wrote over 800 publications in six languages, and exerted a noticeable influence upon analytical jurisprudence globally. Hence, the two first papers in the issue present selected aspects of his legal theory. ${ }^{64}$ The third paper touches upon the single most significant research issue of

64 See Marek Zirk-Sadowski, “Jerzy Wróblewski's Legal Theory and His Influence on Humanist Legal Thought" and Tomasz Bekrycht, "Jerzy Wróblewski's Concept of Legal Interpretation in its Axiological and Epistemological Context" both in this issue of the Review. 
Poland's post-War jurisprudence - that of legal interpretation. ${ }^{65}$ Four further papers single out some of the most significant Polish legal theorists of the period, three belonging to the analytical school (Józef Nowacki, ${ }^{66}$ Zygmunt Ziembiński ${ }^{67}$ and Kazimierz Opałek ${ }^{68}$ ), and the fourth combining legal theory with the sociology of law (Wiesław Lang ${ }^{69}$ ). Following that, the outsider of Poland's post-War legal theory - the legal realistStanisław Ehrlich - is presented, ${ }^{70}$ who is currently the object of a well-deserved rediscovery in contemporary Polish jurisprudence. Following this overview of authors who worked mainly during the socialist period, the penultimate paper presents the ideas of Artur Kozak - author of the innovative theoretical project of juriscentrism. ${ }^{71}$ The issue is closed by a paper exploring the critical inspirations in Poland's post-War jurisprudence and their use in current discourse on the rule of law. ${ }^{72}$

\section{Acknowledgment}

As regards Rafał Mańko, his part of the paper has been prepared as part of National Science Centre, Poland, project no. 2016/21/B/HS5/o0164. The paper presents exclusively the personal views of the authors.

65 Mariusz Jerzy Golecki, Bartosz Wojciechowski, "Conceptualising Judicial Application of Law in the Polish Theory of Legal Interpretation," in this issue.

66 Sławomir Tkacz, "Józef Nowacki as a Theoretician of Normativism in Poland," in this issue.

67 Marzena Kordela, "Zygmunt Ziembiński and his Analytical Theory of Law. Formalization of Law as an Instrument to Protect its Minimal Moral Content," in this issue.

68 Urszula Kosielińska-Grabowska, "Kazimierz Opałek and Alf Ross on Directives and Norms: A Comparative Study," in this issue.

69 Milena Korycka-Zirk, "Wiesław Lang's Legal Thought - Between Sociological and Analytical Jurisprudence," in this issue.

70 Wojciech Zomerski, "Stanisław Ehrich's Critique of Legal Dogmatics: Then and Now," in this issue.

71 Rafał Mańko, op.cit. note 50.

72 Adam Sulikowski, "The Return of Forgotten Critique: Some Remarks on the Intellectual Sources of the Polish Populist Revolution," in this issue. 